\title{
ENT Pathologies Screening in Woodworkers in Parakou, Benin
}

\author{
Spero H. Raoul Hounkpatin1, Fabien A. C. Gounongbe1, Sonia Lawson Afouda², \\ Marius C. Flatin1, Karl A. F. B. Dossou-Kpanou1, François Avakoudjo², \\ Elvire Dossoumou', Wassi Adjibabi ${ }^{2}$ \\ ${ }^{1}$ Faculté de Médecine, Université de Parakou, Parakou, Benin \\ ${ }^{2}$ Faculte des Sciences de la Santé de Cotonou, Université d'Abomey-Calavi, Cotonou, Bénin \\ Email: speraoul@yahoo.fr
}

Received 5 September 2014; revised 4 October 2014; accepted 3 November 2014

Copyright (C) 2014 by authors and Scientific Research Publishing Inc.

This work is licensed under the Creative Commons Attribution International License (CC BY). http://creativecommons.org/licenses/by/4.0/

(c) (7) Open Access

\begin{abstract}
Wood dust may induce health risks on exposed timber or wood workers, one of which is ENT disorders. This article aimed to detect ENT pathologies found among woodworkers in Parakou. It was a cross-sectional descriptive study carried out from $1^{\text {st }}$ March to $31^{\text {st }}$ May, 2012 in Parakou, NorthBenin. It involved 703 carpenters and sawyers operating in timber workshops in Parakou, regardless of age and sex. The mean age of the wood-workers was $26.14 \pm 7.77$ years. Their seniority in the timber profession was on average $4.9 \pm 2.64$ years. All of them were males. It had been noticed that $81.6 \%$ of them did not comply with any safety measure for their protection. ENT pathology had been diagnosed in $60.3 \%$ of the timber workers. Rhinitises came first and affected $43.1 \%$ of the workers, followed by pharyngitises $(14.1 \%)$. The histological nature of the only case of tumor observed in Parakou could not have been specified, as the patient refused to undergo anatomopathological examination. Measures should be taken to get Parakou timber workers to protect themselves.
\end{abstract}

\section{Keywords}

Timber/Wood-Workers, Occupational Rhinitis, ENT Pathologies

\section{Introduction}

Timber dust may induce pathologies like respiratory disorders in particular, including ENT-related ones on exposed timber workers [1]. The carcinogenic effects of wood dusts are well-known for many years and their responsibility in nose and sinus cancers is well established [1]-[3]. Wood dust is also responsible for non-carci- 
nogenic diseases like rhinitises. Several studies had been globally dedicated to non-carcinogenic respiratory pathologies induced by occupational exposure to wood dust [4] [5].

In Africa where the working conditions are different from those of developed countries in which most of the studies are conducted, few articles have been devoted to the diseases induced by occupational exposure to wood dust. In Benin, up to this day, any study of screening of ENT disease among woodworkers has been realized. This one was carried out in order to screen the ENT pathologies found among Parakou timber workers in the north of Benin.

\section{Methods}

The study was a cross-sectional study with descriptive purpose based on a collection of prospective data. It was conducted from $1^{\text {st }}$ March to $31^{\text {st }}$ May, 2012 in the District of Parakou. The target population consisted of carpenters and sawyers working in workshops in Parakou, regardless of age and sex. In Parakou, carpenters and sawyers work in open-air workshops spread out over the town, by the streets or in empty compounds.

Using membership register, all the 749 wood-workers who were members of the three trade unions of the town were selected for the study. However only 703 wood-workers were included in the study; 46 woodworkers refused to participate because according to them, the study would disturb their work and was not profitable for them.

Data were collected, on the one hand, through an individual questionnaire submitted to timber workers, and on the other hand, through the ENT clinical examination of the latter. The clinical examination had particularly explored the ear canal and the eardrum with an otoscope, then the nasal cavity by means of anterior rhinoscopy as well as the oropharynx.

The studied variables were socio-demographic data (age, sex, type of timber work, seniority in the profession), ENT history, presence of ENT pathologies and the suggested diagnosis. Epi-info 3.5.1 software was used for the processing of collected data.

\section{Results}

\subsection{Socio-Demographic Profile of Participants}

The 703 timber workers selected for the study based on inclusion criteria were all males. There were 607 carpenters (86.3\%) and 96 sawyers (13.7\%). The mean age of the timber workers was $26.14 \pm 7.77$ years with extremes from 9 years and 60 years and a median of 26 years. Table 1 reports workers' distribution according to age.

Most of the timber workers (79.2\%) were aged from 15 to 34 years. Only 9.8\% were 34 year old and above.

\subsection{Respondents' Seniority in the Profession}

The respondents' seniority in wood work was on average $4.9 \pm 2.64$ years with extremes of 1 month and 25 years. The median was 5 years. Table 2 represents the distribution of the investigated workers according to their seniority.

\subsection{Knowledge of the Risks Related to Timber Professional Activity and Protection Measures}

Among the 703 respondents, 549 (78.1\%) were aware of the risks related to their professional activity and 154

Table 1. Distribution of wood-workers according to age.

\begin{tabular}{ccc}
\hline & Number & Percentage (\%) \\
\hline Under 15 years & 77 & 11 \\
$15-24$ years & 244 & 34.7 \\
$25-34$ years & 313 & 44.5 \\
$35-44$ years & 59 & 8.4 \\
45 years and above & 10 & 1.4 \\
Total & 703 & 100.0 \\
\hline
\end{tabular}


Table 2. Distribution of wood-workers according to seniority.

\begin{tabular}{cccc}
\hline & Number & Percentage (\%) \\
\hline Under 1 year & 18 & 2.6 \\
$1-5$ years & 259 & 36.8 \\
6 - 10 years & 237 & 33.7 \\
Above 10 years & 189 & 26.9 \\
Total & 703 & 100.0 \\
\hline
\end{tabular}

(21.9\%) ignored about them. However 582 timber workers i.e. 81.6\% did not observe any safety measure for their protection. A bib was used as a protection measure by 117 timber workers (16.6\%). The other protection measures used (1.8\%) were glasses and a headset, each by one timber worker. Two timber workers used a combination of the three protection measures.

\subsection{History of Morbidity among the Respondents}

Out of the 703 respondents, 315 (44.8\%) reported having suffered at least once from an ENT pathology. Table 3 summarizes the distribution of wood/timber workers according to ENT pathological history.

Almost nine wood workers out of ten had a previous history of rhinitis.

\subsection{Pathologies Diagnosed in the Respondents}

Among the 703 respondents, 60.3\% were diagnosed as carriers of an ENT disorder. Table 4 summarizes the distribution of respondent workers according to the diagnosed ENT pathology.

The main ENT pathologies diagnosed were rhinitis and pharyngitis.

\section{Discussion}

The wood-workers of our cohort were young with a mean age of 26.14 years. They were younger than their counterparts from Lille in France (mean age: 35.4 years), from Italy (mean age: 37.8 years) [6] [7]. The Parakou timber workers' young age could be explained by many factors: youthfulness of the Benin population in general, early school dropout and the fact that in Benin, many craftsmen or skilled workers leave their profession to perform other more profitable activities at the earliest opportunity. The great physical effort required by timber work in the developing countries due to lack of adequate tools for this work may justify the absence of female workers. In Lille, Frimat et al. reported 2\% of female timber workers [6]. In a Lithuanian cohort, Smailyte et al. had found a higher female presence (29\%) [8]. In the south-east of Nigeria, neighboring and developing country like Benin, Aguwa et al. reported 491 men and 50 women but the latter were busy with collecting and selling sawdust generated by men's work [9].

Nearly half of the workers indicated having ENT case history and among the reported pathologies, rhinitis came well ahead followed by anginas. The rate of ENT pathologies (associated or not with sawdust) detected in Parakou's timber workers based on the questionnaire and ENT clinical examination, was relatively significant (60.3\%). An Italian study carried out in 2007 by Belvilacqua et al. in a population of timber workers, reported a $32.7 \%$ rate of ENT affections in timber workers [7]. This difference could a priori be associated with the absence of individual and collective protection among Parakou timber workers as is the case in the developed countries but also with the fact that all the ENT pathologies had been taken into account, whether related or not to timber work.

Rhinitises came first among ENT pathologies as well as ENT case history in Parakou timber workers. Rhinitis is a pathology which is often reported in timber workers [5]-[7] [9]. According to Garnier [10], rhinitis is one of the most common occupational diseases. As it causes little disability, it is often neglected by the concerned persons. It is generally misunderstood by physicians, whose knowledge of occupational pathologies and their causes is frequently insufficient. It is due not only to sawdust but also to timber-related allergens. In Parakou, rhinitis rate is close to the one of the developed countries [7] [11] [12]. It is significantly lower than the one found by Aguwa in Nigeria where timber workers are gathered in timber work markets consisting of poorly ventilated workshops and without any method for sawdust removal [9]. In Parakou, almost all the workshops are 
Table 3. Distribution of wood-workers according to ENT history.

\begin{tabular}{ccc}
\hline & Number $(\mathrm{N}=315)$ & Percentage \\
\hline Rhinitises & 277 & 87.9 \\
Anginas & 22 & 7.0 \\
Otitises & 13 & 4.1 \\
Sinusitises & 3 & 1.0 \\
\hline
\end{tabular}

Table 4. Distribution of wood-workers according to the diagnosed ENT pathology.

\begin{tabular}{|c|c|c|}
\hline & Number $(\mathrm{N}=703)$ & Percentage \\
\hline Rhinitis & 303 & 43.1 \\
\hline Pharyngitis & 99 & 14.1 \\
\hline Ear wax & 43 & 6.1 \\
\hline Deafness suspicion ${ }^{*}$ & 24 & 3.4 \\
\hline Average chronic otitis & 10 & 1.4 \\
\hline Otitis externa & 6 & 0.9 \\
\hline Acute otitis media & 3 & 0.4 \\
\hline Nasal tumor $^{* *}$ & 1 & 0.1 \\
\hline No pathology screened & 279 & $39.7 \%$ \\
\hline
\end{tabular}

* Only with sawyers. ${ }^{* *}$ Histological examination not done, as the patient refused to do it.

installed in the open air, on street corners and isolated. This helps reduce substantially sawdust concentration in the air (which we did not measure), but at the expense of the environment.

A pharyngitis case had been found in 14\% of timber workers in Parakou. In Italy, Veneri et al. reported 17.1\% of pharyngitis cases and found a statistically significant relationship with sawdust [11].

The histological nature of the only tumor case observed in Parakou could not have been specified, since the patient refused to undergo the anatomo-pathological examination. However, we assume it was a non-malignant tumor considering its clinical characteristics, and not an adenocarcinoma. Moreover, in the studies where nasosinusal cancers in timber workers had been reported, workers have always been exposed for a long period. Thus, in their studies, Mayr et al. as well as Bimbi et al. reported average exposure duration of 32.3 years in patients suffering from cancer associated with timber [13] [14]. The duration of average exposure of timber workers to sawdust in our study was 4.9 years, which does not give enough ground to associate the tumor observed to timber work.

We suspected $6 \%$ of deafness in timber workers, especially sawyers only. This deafness could be associated with a long and frequent exposure to noise insofar as only two patients among the workers protected themselves from noise.

In general, the other ENT pathologies screened in this study (ear wax and otitises) are not considered as an outcome of the exposure to sawdust.

\section{Conclusion}

ENT pathologies are relatively frequent among timber workers in Parakou. Among those pathologies, the most frequent ones are cases of rhinitis and sinusitis the relationship of which with wood work is well known. Everything still remains to be done as regards protection and prevention in this profession, both at individual and collective levels. At least wood workers should be encouraged to use dust masks; they should wet regularly the floor of their workshops to prevent the dust to be airborne. For this purpose, information and awareness/sensitization programmes should be implemented and protection standards imposed by public authorities.

\section{References}

[1] Mirza, S. (2010) Risks to the Health of Wood Workers: What Can Be Done? Zigazag Journal of Occupational Health and Safety, 3, 1-8. http://www.zjohs.eg.net/pdf/vol3no1/1.pdf 
[2] Hemelt, M., Granström, C. and Hemmenki, K. (2004) Occupational Risks for Nasal Cancer in Sweden. Journal of Occupational and Environmental Medicine, 46, 1033-1040. http://dx.doi.org/10.1097/01.jom.0000141653.30337.82

[3] Imbernon, E. (2003) Estimation of the Number of Some Cancer Cases Attributable to Occupational Factors. http://fulltext.bdsp.ehesp.fr/Invs/Rapports/2003/rapport_cancer_pro.pdf

[4] Jacobsen, G., Schaumburg, I., Sigsgaard, T. and Schhüssen, V. (2010) Non-Malignant Respiratory Disease and Occupational Exposure to Wood Dust. Part I. Fresh Wood and Mixed Wood Industry. Annals of Agricultural and Environmental Medicine, 17, 15-28.

[5] Jacobsen, G., Schaumburg, I., Sigsgaard, T. and Schhüssen, V. (2010) Non-Malignant Respiratory Disease and Occupational Exposure to Wood Dust. Part II. Dry Wood Industry. Annals of Agricultural and Environmental Medicine, 17, 29-44,

[6] Frimat, P., Leroyer, A., Beuneu, A., Dubrulle, F., Larroque, G., Fontaine, B., et al. (2002) Screening of Nasosinusal Pathologies in Employees Exposed to Sawdusts. National Days for Occupational Health in the Construction and Public Works Sector, Lille, 79-64.

[7] Bevilacqua, I., Magnavita, N., Becchetti, G., De Matteis, B., Giunta, G., Lancia, F., et al. (2007) Vigilance on Health Surveillance in Wood Sector. Giornale Italiano di Medicina del Lavoro ed Ergonomia, 29, 794-795.

[8] Smailyte, G. (2012) The Incidence of Cancer among Workers Exposed to Timber Dust in Lithuania. Journal of Occupational and Environmental Medicine, 69, 449-451. http://dx.doi.org/10.1136/oemed-2011-100253

[9] Aguwa, F., Okeke, T. and Asuzu, M. (2007) The Prevalence of Occupational Asthma and Rhinitis in Woodworkers in South-Eastern Nigeria. Tanzania Health Research Bulletin, 9, 52-55. http://dx.doi.org/10.4314/thrb.v9i1.14293

[10] Garnier, R., Villa, A. and Chataigner, D. (2007) Occupational Rhinitises. Respiratory Disease Review. Revue des Maladies Respiratoires, 24, 205-220. http://dx.doi.org/10.1016/S0761-8425(07)91043-8

[11] Veneri, I., Caso, M.A., Ravaioli, M., Albonetti, A., Ghini, P., Mazzavillani, M., et al. (2007) Study on the Prevalence of Respiratory Upper and Lower Tract with Carpenters, Data Monitoring Reports and Medical Records of Exposure. Giornale Italiano di Medicina del Lavoro ed Ergonomia, 29, 833-835.

[12] Milanowiski, J., Góra, A., Skorska, C., Krysińska-Traczyk, E., Mackiewicz, B., Sitkowska, J., et al. (2002) Work-Related Symptoms among Workers in Furniture Factory in Lublin Region (Eastern Poland). Annals of Agricultural and Environmental Medicine, 9, 99-103.

[13] Mayr, S.I., Hafizovic, K., Waldfahrer, F., Iro, H. and Kutting, B. (2010) Characterization of Clinical Symptoms and Risk Factors for Sino-Nasal Adenocarcinoma: Results of a Case-Control Study. Archives of Environmental and Occupational Health, 83, 631-616. http://dx.doi.org/10.1007/s00420-009-0479-5

[14] Bimbi, G., Saraceno, M.S., Riccio, S., Gatta, G., Licitra, I. and Cantù, G. (2004) Adenocarcinoma of Ethmoid Sinus: An Occupational Disease. Acta Otorhinolaryngologica Italica, 24, 199-203. 
Scientific Research Publishing (SCIRP) is one of the largest Open Access journal publishers. It is currently publishing more than 200 open access, online, peer-reviewed journals covering a wide range of academic disciplines. SCIRP serves the worldwide academic communities and contributes to the progress and application of science with its publication.

Other selected journals from SCIRP are listed as below. Submit your manuscript to us via either submit@scirp.org or Online Submission Portal.
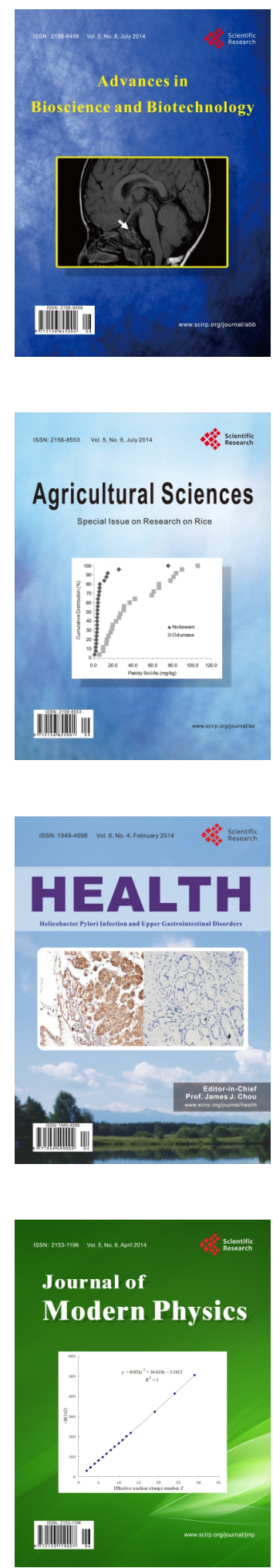
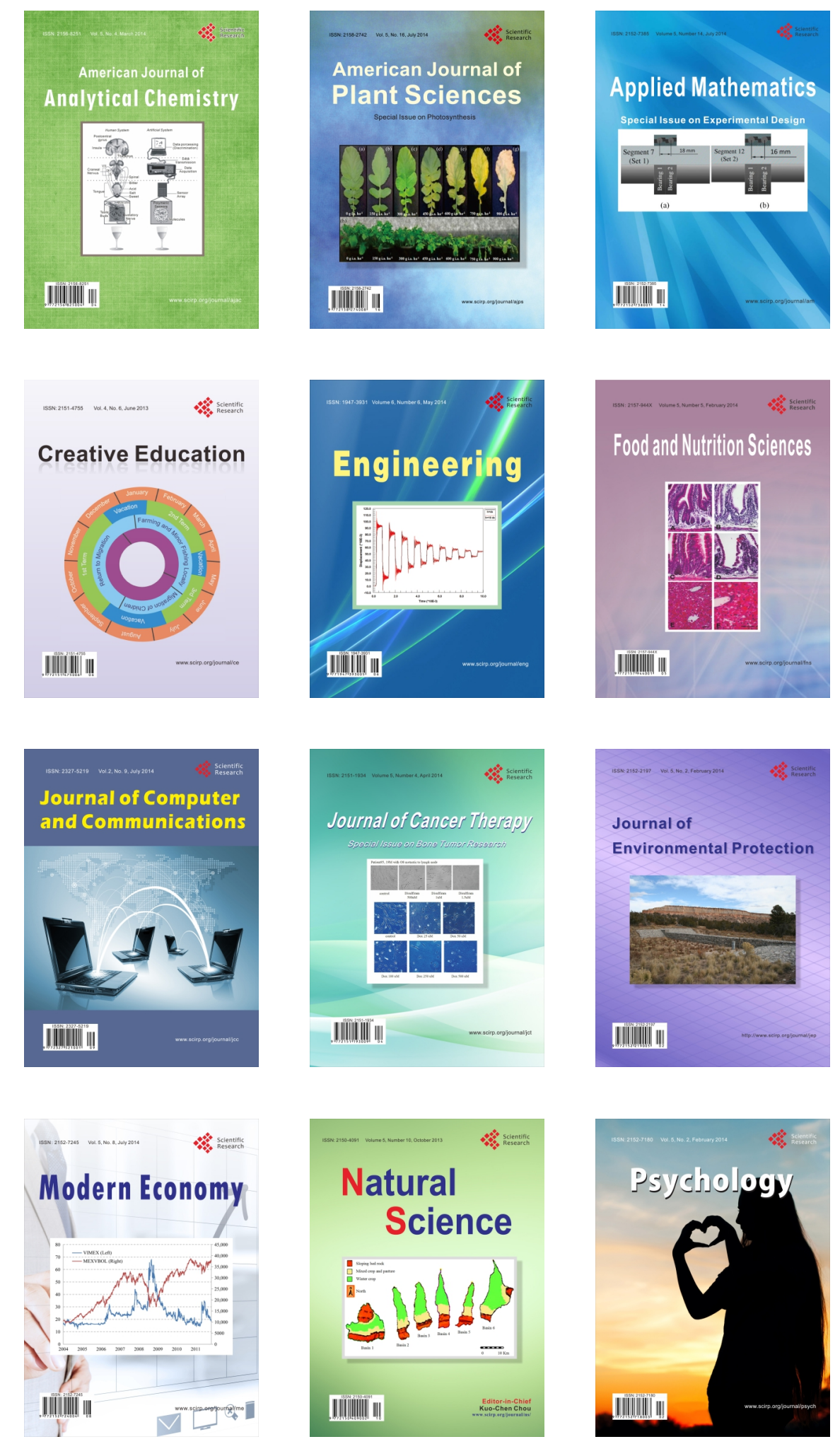